\title{
慣性力影響下での旋回噴流の挙動についての研究*1 Study on the Behavior of Swirling Jets under the Influence of Inertial Forces
}

\author{
丸山 祐 一*2 \\ Yuichi MARUYAMA
}

Key Words : V/STOL, Computational Fluid Dynamics, Jets, Swirling Flows, Coriolis Force

\begin{abstract}
In STOL, it is a critical factor to maintain lifting force stably at low speed. For this purpose, a jet from the engine flows along the wing surface to create a large uptrend centrifugal force which yields an additional uplift force on the wing. In this research, numerical calculation using the Large Eddy Simulation method is performed to find out about this special characteristic of a jet under the influence of inertial forces. It is observed that the secondary flow appears within the jet and its vicinity. The pressure gradient normal to the wing surface, which creates the lift force, is increased by the addition of the jet. It is also observed that the jet center moves relatively to the reference frame adopted in the simulation, and the direction of the movement slightly deviates from the centrifugal force if the jet is swirling. At the initial time, the mean flow is distributed axisymmetrically, and it is shown that the inhomogeneous distribution of Coriolis force, which is due to the swirl, causes most part of the jet center's spanwise movement. In the course of time, however, the influence of advection in the plane perpendicular to the jet magnifies the spanwise movement.
\end{abstract}

\section{1. ま え がき}

短距離離着陸航空機（STOL）においては, 低速飛行時 の揚力確保が重要な課題となっている。 そのための一つの 方策として, ジェットエンジンから出る噴流を翼の上面あ るいは下面に沿って流し, 大きな上向きの遠心力の発生に よって高揚力を得るという方法が考えられている.

例えば，翼上面に沿って噴流を流す場合，翼面が上に凸 の形に反っているため, コアンダ効果により噴流が下に曲 げられ，このとき噴流中に発生する上向きの遠心力は，噴 流が存在しない場合よりも大きな力となり, その結果, 翼 の上側を流れる流体はより強い力で翼面から引き離され, 翼上面での圧力低下も大きくなるので, 揚力の増大効果が 見込める.この方式は Upper Surface Blowing (USB) と 呼ばれているが, 循環制御翼 (Circulation Control Wing: $\mathrm{CCW})$ と呼ばれる方式1,2) も, 噴流を造り出す手段や吹き 出し位置が USB とは異なっていることを除けば, 同じ原 理により揚力を増大させていると考えられる。一方, 翼下 面に沿って噴流を流す場合も，同様に噴流が翼面に沿って 下に曲げられるため, 上向きの遠心力が増加し, より強い 力で翼下面に押しつけられるため, 発生する揚力が増加す る. なお, 同じ原理による揚力増大効果は, 翼の前縁側にエ ンジンの付いたプロペラ機においても生じていて，プロペ ラの影響のない場合よりも高揚力を発生していると考えら

\footnotetext{
*1 (C) 2014 日本航空宇宙学会

平成 22 年 6 月 24 日, 第 42 回流体力学講演会/航空宇宙数值シ ミュレーション技術シンポジウム 2010 において発表. 平成 24 年 4 月 22 日原稿受付

*2 岡山理科大学
}

れる．また，多くの船舶ではスクリューの後流が舵の両側 を通過するように配置されていて, 舵角を取った際にはス クリューにより加速された流れが舵によって曲げられ，ス クリューの存在しない場合よりも大きな横力を発生するが, このときにも上述のケースと同様の効果が働いていると考 えられる。

いずれの場合も，噴流あるいはプロペラやスクリューの 後流は遠心力などの力を受けるため, 二次流れを含む複雑 な挙動を示す. 従って, 揚力増大効果にこれらの要因が様々 な形で影響を及ぼす可能性がある。湾曲した壁面に沿う噴 流については，多くの実験結果が報告されていて，凸面壁 に沿う流れ ${ }^{3,4)}$ ，凹面壁に沿う流れ ${ }^{5,6)}$ ，あるいはその双方7) について, 平均速度分布, 壁面圧力分布, 乱れ速度およびレ イノルズ応力の分布, 二次流れ，噴流の幅の広がりなどが 詳しく調べられている。ただし,これらの実験はいずれも 壁面に対して静止した流体中に噴流が噴出する場合を扱っ ていて，上述の例のように，噴流などの外側の領域でも壁 面に相対的な流れが存在するケースに対応した研究の報告 は見つからなかった。

また，一般にジェットエンジンから排出される流れは， タービンを通ってくるため, らせん状に旋回していると考 えられ, 遠心力, コリオリ力などの慣性力と旋回との相互 作用が工学的に何らかの影響を及ぼす可能性もある。この ような相互作用は, 旋回がより強いプロペラやスクリュー の後流においては，より顕著な形で現れるだろう。しかし ながら調査した範囲内では，旋回している噴流が曲面壁に 沿って流れるケースを扱った実験や数值シミュレーション についての報告は見つからなかった。 
本研究においては，これらの効果や相互作用を詳しく調 べるため, 湾曲した翼面に沿って流れる噴流の数值解析を 行った，解析手法としては, 乱流解析用のラージ・エディ . シミュレーション法 (LES 法) を用い, 流れ場をコンピュー タで扱うための離散化には擬スペクトル法を用いた。

\section{2. 計 算 手 法}

数值解析に用いたモデルとして，第 1 図 (a), (b) に示し たように翼面は上に凸の円弧形とし，噴流を含む流れもそ の形に沿うものとした，本研究においては，流れ場の一部 を図のように直方体の形に切り取った部分のみを計算領域 とし，この領域は，初期時刻における噴流中心の流速と噴 流の外側の流速とを平均した速さで翼面に沿って移動して 行くものとした，従って, 計算結果としてょり遅い時刻で の現象として現れるものは, 翼面に沿ったより下流の位置 での現象を表すことになる。また，計算領域内に設定した $x$ 軸（初期条件における噴流の方向）と $y$ 軸（スパン方向） は常に翼面に接する方向に， $z$ 軸は常に翼面に垂直に保た れ，座標原点は翼面に沿って移動するものとする，従って， 座標基準系は非慣性系となり, この系で立てた運動方程式 には見かけの力，すなわち慣性力の項が加わることになる。 本ケースでは，座標基準系は翼面の曲率中心のまわりに一 定角速度で回転しているので, 慣性力としては遠心力とコ リオリカが現れる。

境界条件は以下のように設定した，翼の上側を噴流が流 れる方式をシミュレートする場合は下側の境界面を, 翼の 下側を流れる方式の場合は上側の境界面をそれぞれ翼面と した上で，それらの境界面には非透過境界条件を，それ以 外の境界面には周期境界条件を課した。非透過境界条件設 定のため，該当する境界面の外側に仮想的な空間を設け，実 空間と仮想的な空間内での速度分布が互いに鏡像の関係を 保つように仮想空間内での初期速度分布と慣性力の分布を 工夫し，さらに両空間を合わせた領域で連続の式を成り立 たせた，乱れの存在する境界面に周期境界条件を用いるこ とで，流れ場の中に人為的に設定した境界面上で計算技術 上の原因で乱れが抑えられることを防いでいる。もち万ん， 周期条件自体は実際の流れ場に課されているものではない が，計算領域の幅を乱れの運動エネルギーの大部分を含む フーリエ成分の波長より十分大きく取ることで，この人為 的な条件による実質的な誤差を少なくすることができると 考えられている。

計算領域の実空間内での初期速度分布は，次の形に設定 する。

$$
\begin{aligned}
& u=u_{\mathrm{m}}+u_{\mathrm{f}} \\
& v=v_{\mathrm{m}}+v_{\mathrm{f}} \\
& w=w_{\mathrm{m}}+w_{\mathrm{f}}
\end{aligned}
$$

ここで, $\boldsymbol{u}_{\mathrm{m}}=\left(u_{\mathrm{m}}, v_{\mathrm{m}}, w_{\mathrm{m}}\right)$ は平均流速, $\boldsymbol{u}_{\mathrm{f}}=\left(u_{\mathrm{f}}, v_{\mathrm{f}}, w_{\mathrm{f}}\right)$ は平滑化された乱れ速度を表す。平均流速の分布は, 次の ように設定する(第 2 図を参照).

$$
u_{\mathrm{m}}=-0.5 \Delta u_{0} \cdot \operatorname{erf}(Q)
$$

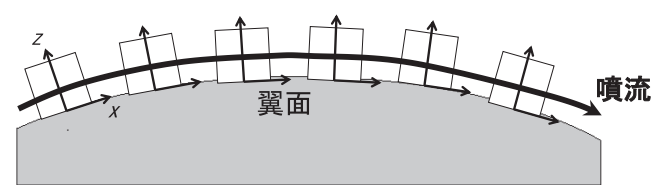

（a）翼の上を噴流が流れる場合

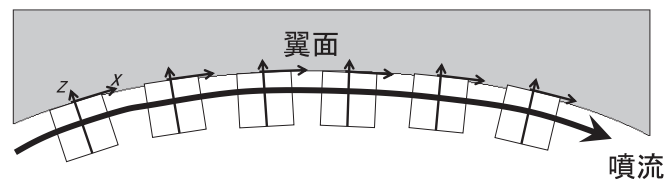

（b）翼の下を噴流が流れる場合

第 1 図 翼面と噴流と計算領域の模式図

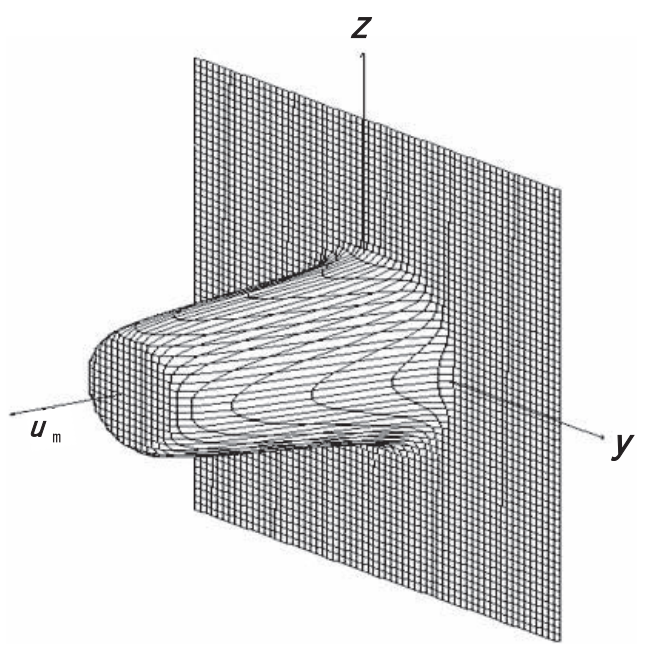

第 2 図 初期時刻の平均流速分布（旋回なしの場合）

$$
\begin{aligned}
& v_{\mathrm{m}}=-0.5 S_{\mathrm{r}} z\{1.0-\operatorname{erf}(Q)\} \\
& w_{\mathrm{m}}=0.5 S_{\mathrm{r}} y\{1.0-\operatorname{erf}(Q)\} \\
& Q=\left(r-d_{0} / 2\right) /\left\{\theta_{0}(2 \pi)^{1 / 2}\right\}
\end{aligned}
$$

ここで, $\Delta u_{0}$ は噴流中心と噴流の外側との流速差， $r$ は噴 流の中心軸からの距離, $d_{0}$ は初期分布における噴流直径, $\theta_{0}$ は初期分布における噴流を囲む剪断層の運動量厚さ, $S_{\mathrm{r}}$ は旋回率である。初期分布における噴流中心軸は，翼の上 側を噴流が流れる場合も下側を流れる場合も，翼面に相当 する境界面から $d_{0}$ の距離に設定した。また，乱れ速度の 場 $\boldsymbol{u}_{\mathrm{f}}$ は, 文献 8) に扔いて一様等方乱流の速度場を生成し たのと同じ方法でベクトル場 $\boldsymbol{\Psi}$ を生成し, $\boldsymbol{\Psi} \exp \left(-Q^{2}\right)$ を ベクトルポテンシャルとして，その回転を取ることにより， 剪断層付近に限定され，な扔かつ連続の式を満たすような 速度分布を生成した9)。

基礎方程式として, 連続の式と, 慣性力項（コリオリ力 と $z$ 方向の遠心力）を加えたナビエ・ストークス方程式 （NS 式）のそれぞれの両辺を，下で述べる方法で平滑化し たものを用いた，ただし，後者の式においては，下で述べる 残余応力項に比べて粘性項が無視できるので, 粘性の影響 自体は陰的に重要な役割を果たしているものの, 見かけ上 はオイラー方程式を平滑化したものと同じ形となっている. これらの基礎方程式の空間偏微分係数の離散化には，擬久 
ペクトル法10) を用いた。この手法では，波長が格子点間隔 の 2 倍を上回るフーリエ成分に関しては，偏微分係数とし て厳密な值を算出しているので, 一般的には他の離散化法 （差分法など）よりも離散化誤差が小さくなると考えられる. さらに, 非線形項の計算時に一旦物理空間に戻して処理す るので, 波数空間内ですべての計算処理を行うスペクトル 法と比較して, フーリエ変換・逆変換の回数は増加するも のの, プログラムの複雑化が避けられる。 その一方で, こ の手法を用いた場合には, エイリアジング誤差の顕在化と いう問題が起こる. エイリアジング誤差とは, 非線形な運 動方程式を離散化して解いた場合に, 非線形項の働きで絶 対值の大きな波数に移動したはずの運動エネルギーが， あ たかも波数の小さい所に戻ってきたかのような現象を起こ して生じる誤差であり, 場合によっては計算を不安定化さ せることもある。本研究においては，パディング法11)を用 いてエイリアジング誤差の除去を行った.

基礎方程式の各項あるいは各物理量の平滑化は, 次式で 表される体積積分により行った。

$$
\bar{f}(\boldsymbol{x})=\int f\left(\boldsymbol{x}^{\prime}\right) G\left(\boldsymbol{x}-\boldsymbol{x}^{\prime}\right) \mathrm{d} \boldsymbol{x}^{\prime}
$$

ここで, $f$ は基礎方程式の各項あるいは各物理量であり, $\bar{f}$ はそれらを平滑化したものである。ただし, 数值解析で直 接取り扱うのは平滑化した量のみであるので，本報告では (3) 式を除いて記号 $\left(^{-}\right)$を省略して表示している. (3) 式右 辺に表れるフィルター関数 $G$ には次式で表されるガウシ アンフィルターを用いた。

$$
\begin{aligned}
& G\left(\boldsymbol{x}-\boldsymbol{x}^{\prime}\right) \\
& \quad=\left\{(6 / \pi)^{1 / 2} / \Delta_{\mathrm{A}}\right\}^{3} \exp \left\{-6\left(\boldsymbol{x}-\boldsymbol{x}^{\prime}\right)^{2} / \Delta_{\mathrm{A}}{ }^{2}\right\}
\end{aligned}
$$

ここで, $\Delta_{\mathrm{A}}$ はフィルターの代表長であり, 本研究では格子 間隔の 3 倍に設定した. 指数関数の前の係数は,「一様なス カラー場を平滑化すれば, 同じスカラー場となる」という 条件から決まる。平滑化によって取り除かれた乱れ, 即ち 格子下レベル（Sub Grid Scale, SGS）の乱れの影響（残 余応力, Residual Stress) は渦粘性モデルを用いて表され る。本研究においては，スマゴリンスキーモデルと渦度モ デルの双方を用いて計算を行ったが，両者による計算結果 の差異は小さいことが確認されたので, 本報告では後者の モデルによる計算結果のみを示し, 代表的な結果について, モデルによる差異の大きさあるいは割合を示した。両モデ ルにおいて, 渦粘性係数 $\nu_{\mathrm{T}}$ に表れる定数は実験結果との 比較により定められる。本研究においては, 作成したプロ グラムを用いて一様等方乱流のテスト計算を行い, エネル ギー散逸率が実験結果 ${ }^{12}$ ) と一致するような值（スマゴリン スキー定数 $C_{\mathrm{s}}=0.18$, 渦度モデル定数 $\left.C_{\mathrm{v}}=0.20\right)$ に設 定した。同時に，この值を用いた場合に，エネルギースペ クトルの時間変化も実験結果をほぼ再現していることを確 認した。

各時刻での圧力場は, 平滑化された NS 式の発散を取る ことにより得られるポアッソン方程式を解いて求めた。 ポ
アッソン方程式の右辺を算出する際に，平滑化された連続 の式を陰的に用いる。 なお， LES 法においては，通常の定 義による圧力と, 残余応力テンソルの三つの対角成分の平 均值に負号を付けたものとを一体として扱っていて, 数值 計算においては，両者は原理的に識別できない，習慣に従っ て，本報告でも両者を合わせたものを「圧力」と呼ぶ.

速度場の時間変化は，平滑化された NS 式における時間 微分演算をアダムス・バッシュフォース法により差分化し て算出した。計算過程で必要となるフーリエ変換と逆変換 には高速フーリエ変換を用いた。

計算に用いた物理量は，長さは初期時刻における噴流直径 $d_{0}$, 速度は同じ時刻での噴流中心と噴流の外側との流速差 $\Delta u_{0}$ を基準值として無次元化した. また, 流体密度 $\rho_{0}$ （一定 值）は $\rho_{0}$ 自身を基準值として無次元化し, 時刻, 圧力, 旋回 率の無次元化は, それぞれ $d_{0} / \Delta u_{0}, \rho_{0} \Delta u_{0}{ }^{2}, \Delta u_{0} / d_{0}$ を基 準值とした。計算領域内に設定した格子の数は $64 \times 64 \times 64$ (実空間内の数), 格子間隔は $\Delta x=\Delta y=\Delta z=0.0625$, 時間ステップ幅 $\Delta t=0.03125$ とした. $x, y$ および $z$ 方向 の計算領域幅は, 初期時刻での噴流直径の 4 倍となる。ま た，初期時刻での剪断層中央部の乱れ速度 $\boldsymbol{u}_{\mathrm{f}}$ の大きさの rms 值は 0.03 に設定し, 計算は倍精度で行った。

\section{3. 計 算 結 果}

3.1 流れ場の概観 計算結果を可視化した一例として, 翼面の上側を噴流が流れるケースにおける， $x$ 軸に垂直な 一断面内での渦度の $x$ 成分の分布を第 3 図に示す。図示し た計算例において, 翼面の曲率半径 $R=40.0$, 初期速度分 布における旋回率 $S_{\mathrm{r}}=0.00$, 噴流内外の（翼面に相対的 な）流速の比率 $V_{\mathrm{r}}=2.00$ であり, 図における時刻 $t=3.0$ である。ここで, $V_{\mathrm{r}}$ は噴流の外側の流速 $U_{\mathrm{a}}\left(\Delta u_{0}\right.$ により 無次元化した值）を用いて,

$$
V_{\mathrm{r}}=\left(U_{\mathrm{a}}+1\right) / U_{\mathrm{a}}
$$

と表される。図において, 噴流の向き（ $x$ 軸）は紙面に垂 直で, 遠心力の方向 $(z$ 軸 $)$ は紙面内で上向きであり, 図 の下端が翼面に相当している，赤色で表示した所は，正の 渦度 (紙面内で時計回り), 青色は負の渦度（反時計回り） を持つ領域を表す。図から明らかなように，噴流付近で二 次流れが発生している。これは, 噴流内外での流速差によ る慣性力の不均一により生ずると考えられている.

次に，同じく翼面の上側を噴流が流れているケースにお いて, 噴流内部の流体が旋回している場合の渦度分布の時 間変化を第 4 図 $(\mathrm{a}) \sim(\mathrm{d})$ に示す $\left(R=40.0, S_{\mathrm{r}}=1.00\right.$, $\left.V_{\mathrm{r}}=2.00, t=0.00 \sim 9.00\right)$. 初期時刻では, (2) 式で設定 したように噴流内部で剛体回転し, 噴流外では回転してい ないので, 噴流内で時計回りの一様な渦度, 噴流外で渦度 がゼロで, その境目の剪断層の所に逆向きの渦度が表れて いる，時間が経つにつれ，渦度の分布がなだらかになり，時 刻 $t=3.00$ あたりから青色（負の渦度）の領域と赤色（正 の渦度）の領域とが分離し始める。これは二次流れの影響 が強くなってきたことによると推測される。両領域は旋回 


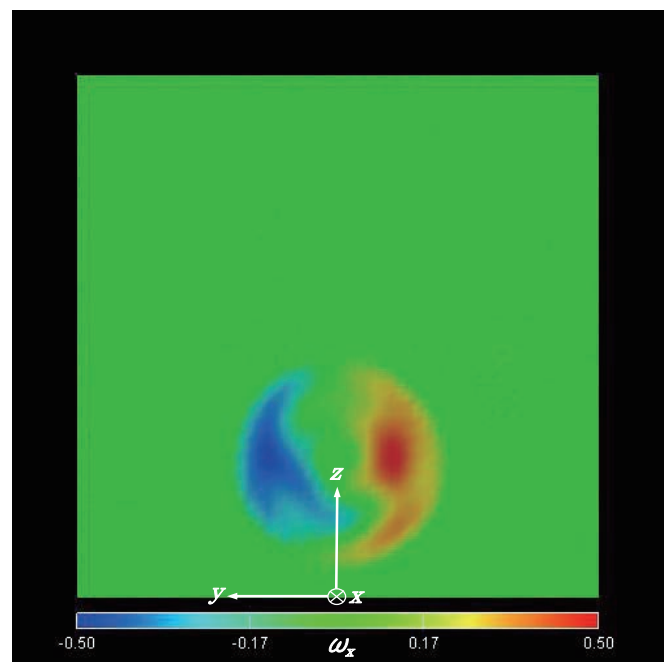

第 3 図 渦度の $x$ 成分の $y z$ 面内での分布（旋回なし）

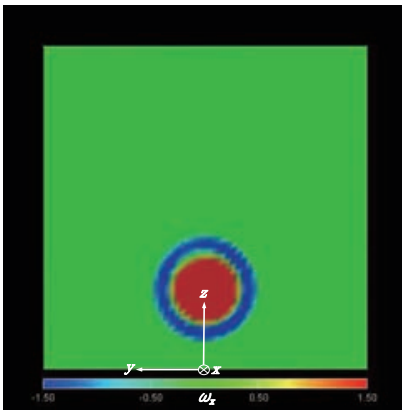

(a) $t=0$

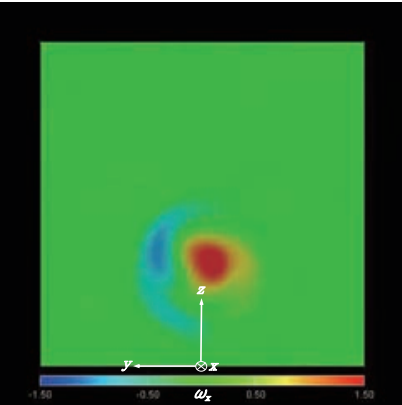

(c) $t=6$

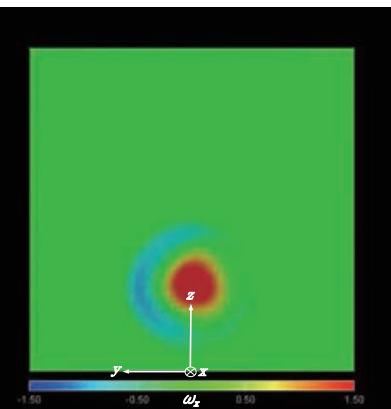

(b) $t=3$

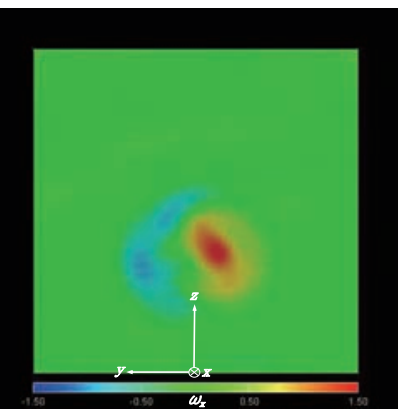

(d) $t=9$
第 4 図 渦度の $x$ 成分の $y z$ 面内での分布（旋回あり）

と同じ向きに回転しながら，遠心力の方向にも少しずつ移 動している.

3.2 圧力勾配の増加 揚力は基本的には $z$ 方向（翼面 に垂直な方向）の圧力勾配 $\partial P / \partial z$ が存在することにより 発生する。即ち, 実際の流れ場においては, 翼の上側と下 側の無限遠で同一の圧力（大気圧）となるため, $z$ 方向の 圧力勾配が存在すれば翼の上下面で圧力差が生じ, それに 対応する揚力を翼は受ける。本研究においては，流れ場の 一部分を切り取って計算しているので，無限遠での境界条 件を課すことはできないが，揚力発生のメカニズム（流線 曲率の定理) が「 $\partial P / \partial z$ の発生」という形で表れているこ とには違いがない. 従って, 噴流の存在による揚力増大効
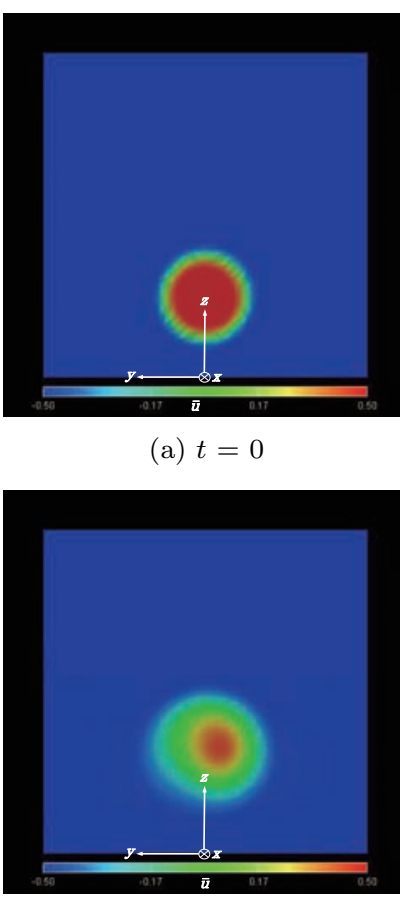

(c) $t=6$ (a) $t=0$

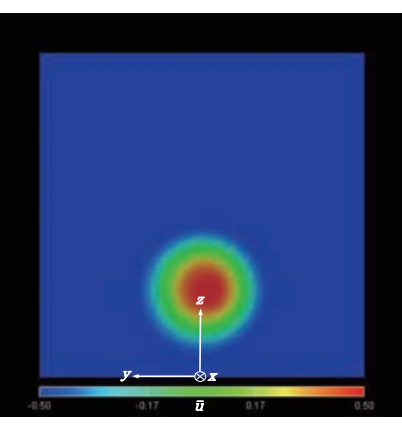

(b) $t=3$

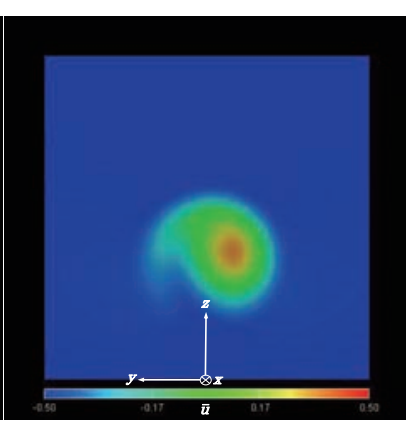

(d) $t=9$
第 5 図 流速の $x$ 成分の $y z$ 面内での分布（翼の上を噴流が流れる 場合）

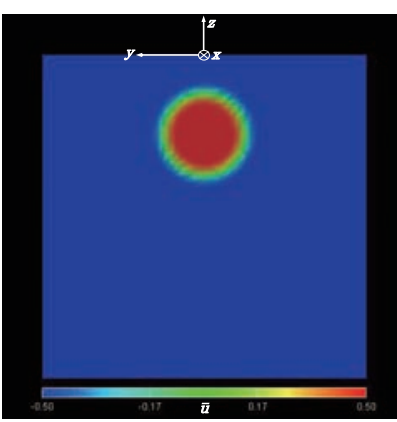

(a) $t=0$

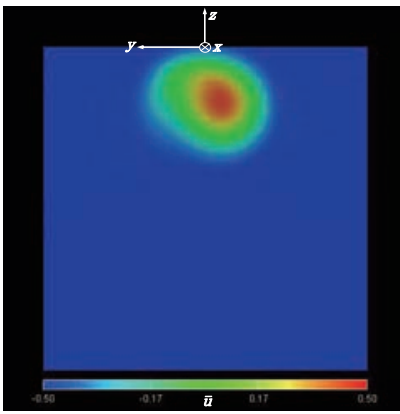

(c) $t=6$

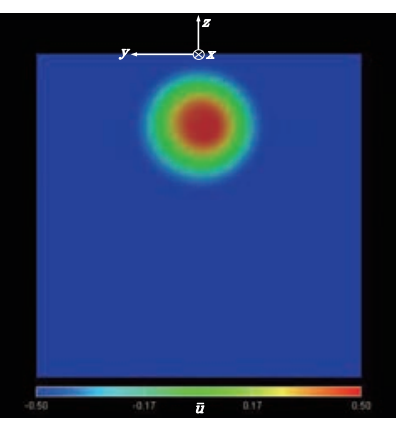

(b) $t=3$

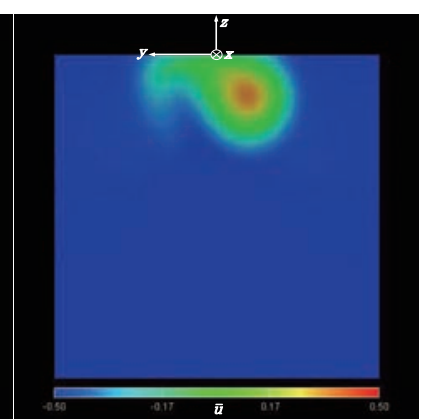

(d) $t=9$

第 6 図 流速の $x$ 成分の $y z$ 面内での分布（翼の下を噴流が流れる 場合）

果を予測するには, $\partial P / \partial z$ の増加量が一つの指標となりう る。比較対象となる「噴流のない場合の圧力勾配」は，遠 心力との釣り合いから理論的に求めることができ,

$$
\partial P / \partial z=(R+z) \omega^{2} / U_{\mathrm{a}}^{2}=(R+z) / R^{2}
$$


第 1 表 圧力勾配の比較

\begin{tabular}{|c|c|c|c|c|c|c|c|c|c|}
\hline & & & & \multicolumn{3}{|c|}{ 噴流：翼の上側 } & \multicolumn{3}{|c|}{ 噴流：翼の下側 } \\
\hline & & & & $\begin{array}{l}\text { 圧力勾配 } \\
\text { (噴流あり) }\end{array}$ & $\begin{array}{l}\text { 圧力勾配 } \\
\text { (噴流なし) }\end{array}$ & $\begin{array}{c}\text { 増加率 } \\
(\%)\end{array}$ & $\begin{array}{l}\text { 圧力勾配 } \\
\text { (噴流あり) }\end{array}$ & $\begin{array}{l}\text { 圧力勾配 } \\
\text { (噴流なし) }\end{array}$ & $\begin{array}{c}\text { 増加率 } \\
(\%)\end{array}$ \\
\hline$R 40$ & $V_{\mathrm{r}} 2.0$ & $S_{\mathrm{r}} 1.0$ & \begin{tabular}{l|l}
$Z_{\mathrm{c} 0}$ & 1.0
\end{tabular} & 0.0289 & 0.0263 & 10.1 & 0.0264 & 0.0238 & 11.1 \\
\hline$R 20$ & $V_{\mathrm{r}} 2.0$ & $S_{\mathrm{r}} 1.0$ & $Z_{\mathrm{c} 0} \mid 1.0$ & 0.0603 & 0.0550 & 9.63 & 0.0503 & 0.0450 & 11.7 \\
\hline$R 60$ & $V_{\mathrm{r}} 2.0$ & $S_{\mathrm{r}} 1.0$ & $Z_{\mathrm{c} 0} \mid 1.0$ & 0.0190 & 0.0172 & 10.2 & 0.0179 & 0.0161 & 10.9 \\
\hline$R 40$ & $V_{\mathrm{r}} 1.5$ & $S_{\mathrm{r}} 1.0$ & $Z_{\mathrm{c} 0} \mid 1.0$ & 0.0276 & 0.0263 & 5.23 & 0.0251 & 0.0238 & 5.74 \\
\hline$R 40$ & $V_{\mathrm{r}} 3.0$ & $S_{\mathrm{r}} 1.0$ & $Z_{\mathrm{c} 0} \mid 1.0$ & 0.0314 & 0.0263 & 19.8 & 0.0289 & 0.0238 & 21.8 \\
\hline$R 40$ & $V_{\mathrm{r}} 2.0$ & $S_{\mathrm{r}} 0.0$ & $Z_{\mathrm{c} 0} \mid 1.0$ & 0.0289 & 0.0263 & 10.1 & 0.0264 & 0.0238 & 11.1 \\
\hline$R 40$ & $V_{\mathrm{r}} 2.0$ & $S_{\mathrm{r}} 0.5$ & $Z_{\mathrm{c} 0} \mid 1.0$ & 0.0289 & 0.0263 & 10.1 & 0.0264 & 0.0238 & 11.1 \\
\hline$R 40$ & $V_{\mathrm{r}} 2.0$ & $S_{\mathrm{r}} 1.5$ & $Z_{\mathrm{c} 0} \mid 1.0$ & 0.0289 & 0.0263 & 10.1 & 0.0264 & 0.0238 & 11.1 \\
\hline$R 40$ & $V_{\mathrm{r}} 2.0$ & $S_{\mathrm{r}} 1.0$ & $Z_{\mathrm{c} 0} \mid 0.5$ & 0.0290 & 0.0263 & 10.6 & 0.0261 & 0.0238 & 10.0 \\
\hline$R 40$ & $V_{\mathrm{r}} 2.0$ & $S_{\mathrm{r}} 1.0$ & $Z_{\mathrm{c} 0} \mid 1.5$ & 0.0289 & 0.0263 & 10.1 & 0.0264 & 0.0238 & 11.1 \\
\hline
\end{tabular}

$R$ : 曲率半径, $V_{\mathrm{r}}$ : 流速比, $S_{\mathrm{r}}$ : 旋回率, $\left|Z_{\mathrm{c} 0}\right|$ : 噴流中心の翼面からの距離.

と表される。ここで， $U_{\mathrm{a}}$ は翼面に接する位置での（翼面 に相対的な）流速の大きさ， $R$ は翼面の曲率半径， $z$ は

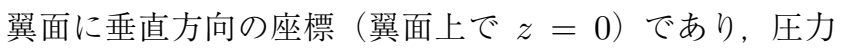
は $\rho_{0} U_{\mathrm{a}}{ }^{2}$ を基準として無次元化した。また, 流体は翼面 の曲率中心まわりに角速度 $\omega\left(=U_{\mathrm{a}} / R\right)$ で剛体回転してい るものとした，例えば $R=40.0$ の場合，翼の上側（凸面 側）の $0.0<z<4.0$ の領域における平均の圧力勾配は, $z=2.0$ を(6) 式に代入して $\partial P / \partial z=2.625 \times 10^{-2}$ とな る. 一方, 同じ $R$ の值に対する噴流のない場合のシミュ レーション計算を流れとともに移動する座標基準系を用い て行うと, 計算領域全体 $(0.0<z<4.0)$ での平均值と して $\partial P / \partial z=2.635 \times 10^{-2}$ が得られ, 理論值とのずれは $0.38 \%$ であった。 また，同じ曲率半径の翼面の下側（凹面 側）を流れる場合には, $-4.0<z<0.0$ における理論值 $\partial P / \partial z=2.375 \times 10^{-2}$ (平均值) に対し, 噴流のない場 合のシミュレーション結果からは $\partial P / \partial z=2.384 \times 10^{-2}$

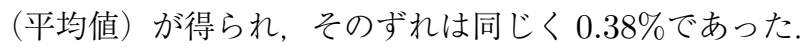

次に, 噴流のある場合について, 翼面の曲率半径, 噴流 内外の流速比, 旋回率, 噴流中心の翼面からの距離を様々 に設定してシミュレーション計算を行い, 圧力勾配（計算 領域全体での平均值）を算出した。ただし，本節での計算 に限り，噴流のない場合の計算と同じ座標基準系（噴流外 部の流れに乗って移動）を用い, 圧力は $\rho_{0} U_{\mathrm{a}}{ }^{2}$ を基準とし て無次元化した。ここで， $U_{\mathrm{a}}$ は噴流外部の流速の大きさ （翼面に対する相対速度）である. 得られた圧力勾配の值 と, それぞれのケースと同じ曲率半径の翼面に沿う「噴流 を含まない流れ」の圧力勾配の理論值，および後者に対す る前者の増加率を第 1 表に示す.

第 1 表より, 噴流がある場合の圧力勾配は, 曲率半径と 流速比により決まり, 旋回率と噴流中心の翼面からの距離 にはほとんど関係しないことがわかる。一方，噴流のない 場合に対する増加率は, 噴流内外の流速比のみによりほぼ 決まることが判明した，また，第 1 表に示したすべてのケー スについて, 渦粘性係数の算出式にスマゴリンスキーモデ ルを用いて同じシミュレーション計算を行ったところ, 圧力 勾配とその増加率ともに, 表示した有効数字の範囲内では 違いが表れなかった。 なお，シミュレーションにおいては，
（非慣性系に固定した）計算領域内で噴流はほぼ真つ直ぐに 流れているため, この点において実際の流れと少し異なっ ている. 即ち, 噴流の曲りにより生ずる効果のうち, 座標基 準系の加速度運動に対応した慣性力の影響（基準系に相対 的な流体速度の寄与分を含む) は算入されているが, 基準 系に相対的な流体加速度の寄与分が入っていない。そのた め, 圧力勾配の増加量が過小評価されている可能性がある.

3.3 噴流中心の移動 噴流に垂直な面内での流速の $x$ 成分 $(x$ 方向の平均值) の分布の時間変化を, 第 5 図 $(\mathrm{a}) \sim$ (d) と第 6 図 $(\mathrm{a}) \sim(\mathrm{d})$ に画像表示する（曲率半径 $R=40.0$, 旋回率 $S_{\mathrm{r}}=1.00$, 噴流内外の流速比 $\left.V_{\mathrm{r}}=2.00\right)$. 第 5 図 では下側の境界, 第 6 図では上側の境界が翼面に相当し, 両図において, 遠心力の方向, 即ち $z$ 軸は紙面内で上向き である。赤色で表示した所で速度が大きく，緑から青色の 領域へと速度が低下していく，初期条件として，噴流内部 に時計回りの旋回を設定している。時刻が経過するにつれ， 噴流の輪郭がぼやけるとともに, 噴流の位置も移動してい く，基本的には遠心力の方向への移動が主であるが, さら に右方向 $(-y$ 方向, 即ちスパン方向 $)$ にも多少とも移動 していることがこれらの画像から読み取れる. 他のケース も含めて，噴流中心が時間とともにどのように移動するか を算出した結果を第 7 図 (a), (b) に示す。ここで, 噴流中 心の座標 $y_{\mathrm{c}}, z_{\mathrm{c}}$ は次式により定義した。

$$
\begin{aligned}
& y_{\mathrm{c}}=\sum_{\text {tot }} u_{i}^{+} y_{i} / \sum_{\text {tot }} u_{i}^{+} \\
& z_{\mathrm{c}}=\sum_{\text {tot }} u_{i}^{+} z_{i} / \sum_{\text {tot }} u_{i}^{+}
\end{aligned}
$$

上式において $u^{+}(=u+0.5)$ は噴流外部の流れに対す る相対速度の $x$ 成分, 添字 $i$ は, 計算領域の実空間内の各 格子点の通し番号, $y_{i}$ および $z_{i}$ は, それぞれ $i$ 番目の格 子点の $y$ 座標と $z$ 座標, $\sum_{\text {tot }}$ は計算領域の実空間内の全 格子点での合計を表す。(7) 式による噴流中心座標の定義 は, 「計算領域の実空間内の各格子点位置に, そこでの $u^{+}$ の值に比例する重みを置いた場合の重心座標」とも解釈で きる。

図において, どのケースでも共通して $z$ 方向への移動 


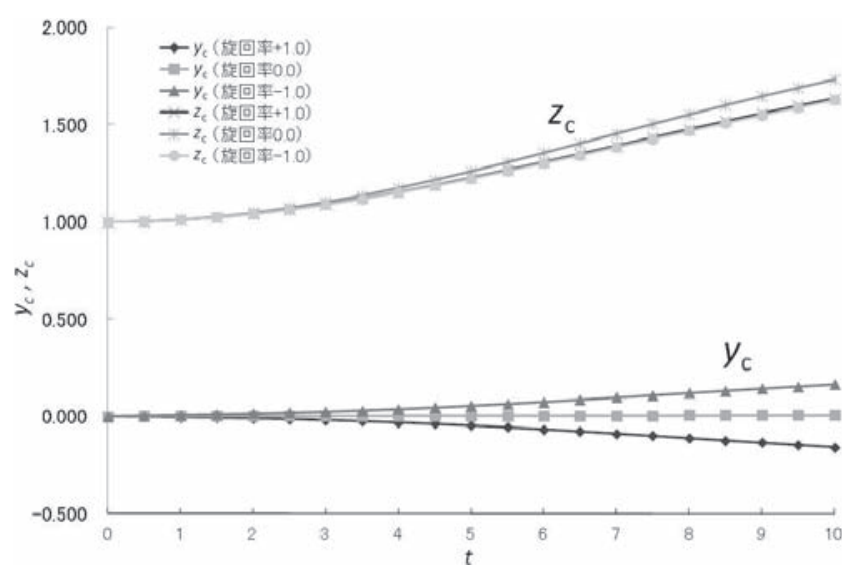

(a) 翼の上を噴流が流れる場合

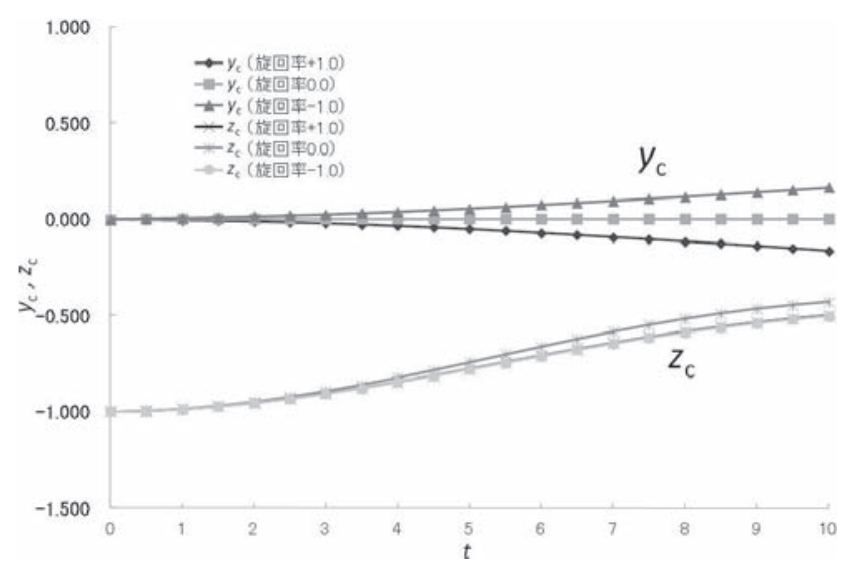

（b）翼の下を噴流が流れる場合

第 7 図 噴流中心座標の時間変化

が見られる，ただし，その移動量は，翼が存在せずに慣性 の法則により直進した場合の值（翼の上側を噴流が流れる 場合 $t=5$ で $0.696, t=10$ で 2.91 の $z$ 方向移動, 下側 を流れる場合 $t=5$ で $0.732, t=10$ で 3.07 の $z$ 方向移 動）よりもずっと小さく, 慣性系から見れば翼面の反りと 同方向に噴流の軌道がシフトしていると言える。一方, $y$ 方向（スパン方向）への移動は旋回の向きによって移動方 向も逆転し, 旋回のない場合は, $y$ 方向にはほとんど移動 していない，このことから，スパン方向への移動と旋回と が密接に関係していることが明らかである。なお，スマゴ リンスキーモデルを用いて同じ計算を行った場合にも第 7 図 (a), (b) と定量的にほとんど同じ結果が得られていて, 初期時刻から計算終了時刻までの $y_{\mathrm{c}}$ の移動量のモデルに よる差異は, 最も大きい場合で $1.5 \%$, 最も小さい場合で 0.23\%（ $y$ 方向にほとんど移動しない旋回率 0 の場合を除 く）であった。 また，同様の比較に打いて， $z_{\mathrm{c}}$ の移動量の モデルによる差異は最も大きい場合で $2.5 \%$, 最も小さい場 合で $0.21 \%$ であった。

計算に用いた座標系において，噴流中心の移動方向が $(+y$ あるいは $-y$ 方向に）曲がる向きと旋回の向きとの関係は, 偶然かもしれないが，マグヌス効果によってボールなどの 軌道が曲がる向きと一致している。もしそのような効果に よる現象であるなら，噴流を形成する流体がまわりの流体
から受ける力 ${ }^{13)}$ がその原因となっているはずである，従っ て，そのことを確認するため，噴流がまわりの流体から受 ける圧力の各成分をシミュレーション結果から算出した，具 体的には，各時刻に扔ける噴流中心軸のまわりに同軸円柱 状の検査面を多数設置し, それらの面に外から加わる圧力 の面積分值の $y$ 成分と $z$ 成分を, 各検査面に近接する格 子点での圧力值から近似的に算出した，得られた結果から， 圧力の面積分值の $y$ 成分の絶対值は, 噴流中心からの距離 によらずほとんどゼロ（ $z$ 成分よりはるかに小さい值）と なっており，噴流の外部の流体から $y$ 方向への力は事実上 作用していないことが判明した，従って，噴流中心が遠心 力と異なる方向に移動する原因は，外部の流体から受ける 圧力によるものではないと推測できる.

噴流中心のスパン方向への移動の原因として別の可能性を 探るため，流体に働くコリオリカに着目した。まず，噴流中 心の $y$ 座標の定義式 (7) 式から, $\mathrm{d} y_{\mathrm{c}} / \mathrm{d} t$ の算出式を以下の ように導出した. $y_{\mathrm{c}}$ の定義式に扔いて, 分母の $\sum_{\mathrm{tot}} u_{i}^{+}=$ 一定となることがシミュレーション結果から確認されてい て, この一定值を $U_{\mathrm{T}}$ と置くと,

$$
\begin{aligned}
\frac{\mathrm{d} y_{\mathrm{c}}}{\mathrm{d} t} & =\frac{\mathrm{d}}{\mathrm{d} t}\left\{\frac{\sum_{\mathrm{tot}} u_{i}^{+} y_{i}}{U_{\mathrm{T}}}\right\} \\
& =\frac{1}{U_{\mathrm{T}}} \sum_{\text {tot }} \frac{\partial u_{i}^{+}}{\partial t} y_{i} \\
& =\frac{1}{U_{\mathrm{T}}} \sum_{\text {tot }} \frac{\partial u_{i}}{\partial t} y_{i}
\end{aligned}
$$

となる．ここで，右辺の微分倸数はそれぞれの格子点での $u_{i}$ の時間変化率であるので, 偏微分記号を用いて表した. 運動方程式より

$$
\begin{aligned}
\frac{\partial u_{i}}{\partial t} & =\frac{\mathrm{D} u_{i}}{\mathrm{D} t}-u_{i}\left(\frac{\partial u}{\partial x}\right)_{i}-v_{i}\left(\frac{\partial u}{\partial y}\right)_{i}-w_{i}\left(\frac{\partial u}{\partial z}\right)_{i} \\
& =\frac{1}{\rho}\left(\boldsymbol{F}_{i}\right)_{x}-u_{i}\left(\frac{\partial u}{\partial x}\right)_{i}-v_{i}\left(\frac{\partial u}{\partial y}\right)_{i}-w_{i}\left(\frac{\partial u}{\partial z}\right)_{i}
\end{aligned}
$$

であるので，(8)式より

$$
\begin{aligned}
\frac{\mathrm{d} y_{\mathrm{c}}}{\mathrm{d} t}= & \frac{1}{U_{\mathrm{T}}} \sum_{\text {tot }}\left\{\frac{1}{\rho}\left(\boldsymbol{F}_{i}\right)_{x}-u_{i}\left(\frac{\partial u}{\partial x}\right)_{i}\right. \\
& \left.-v_{i}\left(\frac{\partial u}{\partial y}\right)_{i}-w_{i}\left(\frac{\partial u}{\partial z}\right)_{i}\right\} y_{i}
\end{aligned}
$$

となる。ここで, $\left(\boldsymbol{F}_{i}\right)_{x}$ は $i$ 番目の格子点において, 単位 体積の流体に加わる力の $x$ 成分である.

(9) 式右辺に表れる $\left(\boldsymbol{F}_{i}\right)_{x}$ のうちコリオリカの寄与分 $\left(\boldsymbol{F}_{\mathrm{CR} i}\right)_{x}$ のみを算入した場合の左辺の值を $\left(\mathrm{d} y_{\mathrm{c}} / \mathrm{d} t\right)_{\text {calc }}$ と 表すと,

$$
\boldsymbol{F}_{\mathrm{CR} i}=-2 \rho \boldsymbol{\omega} \times \boldsymbol{u}_{i}
$$

であるので,

$$
\left(\frac{\mathrm{d} y_{\mathrm{c}}}{\mathrm{d} t}\right)_{\text {calc }}=-\frac{2}{U_{\mathrm{T}}} \sum_{\text {tot }} \Omega w_{i} y_{i}-\frac{1}{U_{\mathrm{T}}} \sum_{\text {tot }} y_{i} u_{i}\left(\frac{\partial u}{\partial x}\right)_{i}
$$




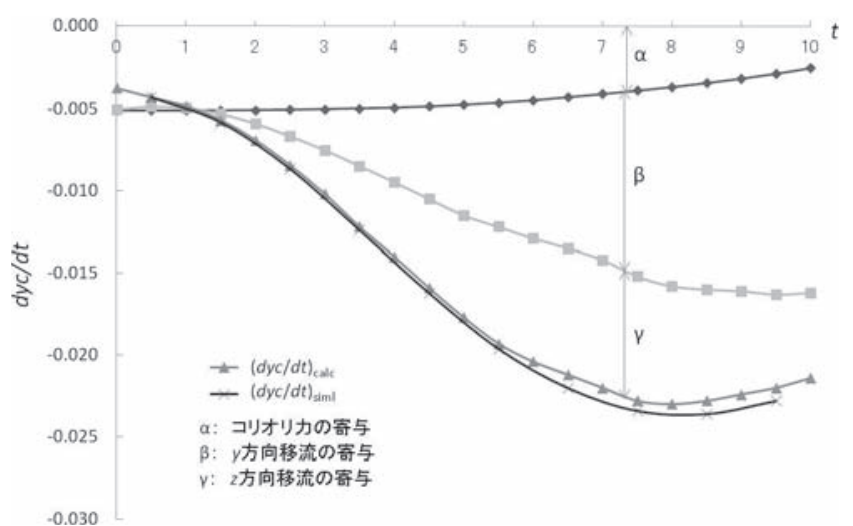

(a) 旋回率 1.0

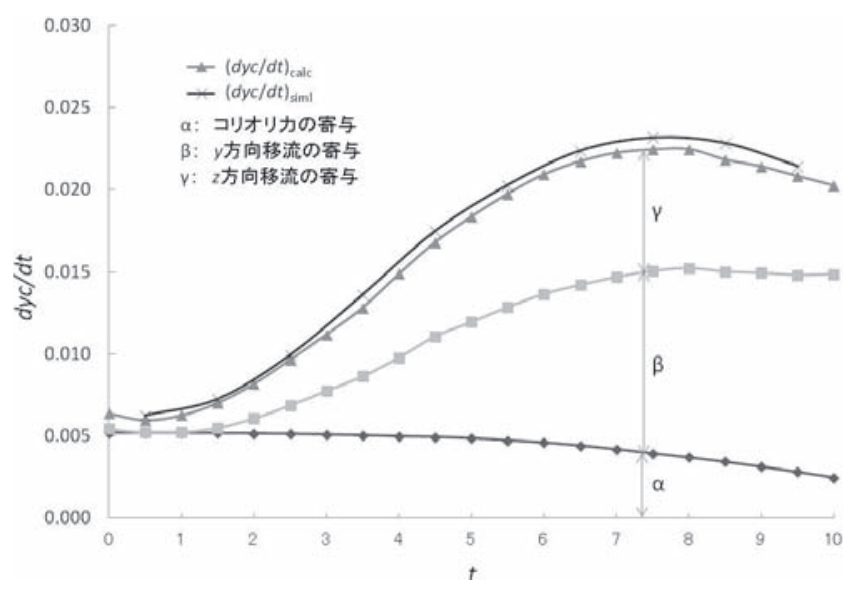

(b) 旋回率 -1.0

第 8 図 噴流中心 $y$ 座標の時間変化率（翼の上を噴流が流れる場合）

$$
\begin{aligned}
& -\frac{1}{U_{\mathrm{T}}} \sum_{\text {tot }} y_{i} v_{i}\left(\frac{\partial u}{\partial y}\right)_{i} \\
& -\frac{1}{U_{\mathrm{T}}} \sum_{\text {tot }} y_{i} w_{i}\left(\frac{\partial u}{\partial z}\right)_{i}
\end{aligned}
$$

となる．ここで， $\boldsymbol{\omega}=(0, \Omega, 0)$ は，シミュレーションに用 いた座標系の回転角速度べクトルである。

噴流が旋回しているケース（曲率半径 $R=40.0$, 旋回 率 $S_{\mathrm{r}}= \pm 1.00$, 噴流内外の流速比 $\left.V_{\mathrm{r}}=2.00\right)$ におい て, 各時刻における流速分布から (10) 式を用いて算出した $\left(\mathrm{d} y_{\mathrm{c}} / \mathrm{d} t\right)_{\text {calc }}$ の值と, シミュレーション結果における噴流 中心の $y$ 座標の時間変化率 $\left(\mathrm{d} y_{\mathrm{c}} / \mathrm{d} t\right)_{\operatorname{siml}}$ とを比較した結果 を第 8 図 (a), (b)（翼の上側を噴流が流れるケース）と第 9 図 (a), (b)（翼の下側を流れるケース）に示す。図中に示 した $\alpha$ は (10) 式右辺の第 1 項, 即ちコリオリ力の寄与に よる部分, $\beta$ で示した部分は第 3 項, 即ち $y$ 方向への移流 の寄与, $\gamma$ で示した部分は第 4 項の $z$ 方向への移流の寄与 を表す.ここで第 2 項は, $u$ に $x$ 方向の周期境界条件が課 されることにより，常に0となる。図から明らかなように, いずれのケースでもすべての時刻において $\left(\mathrm{d} y_{\mathrm{c}} / \mathrm{d} t\right)_{\operatorname{siml}}$ と $\left(\mathrm{d} y_{\mathrm{c}} / \mathrm{d} t\right)_{\text {calc }}$ とはよく一致していて, 流体に加わる力 $((9)$ 式の右辺括弧内の第 1 項）としてコリオリ力のみを考慮し た場合の $y_{\mathrm{c}}$ の移動量の理論值と, シミュレーション結果に おける実際の移動量とがほぼ一致することが判明した。さ

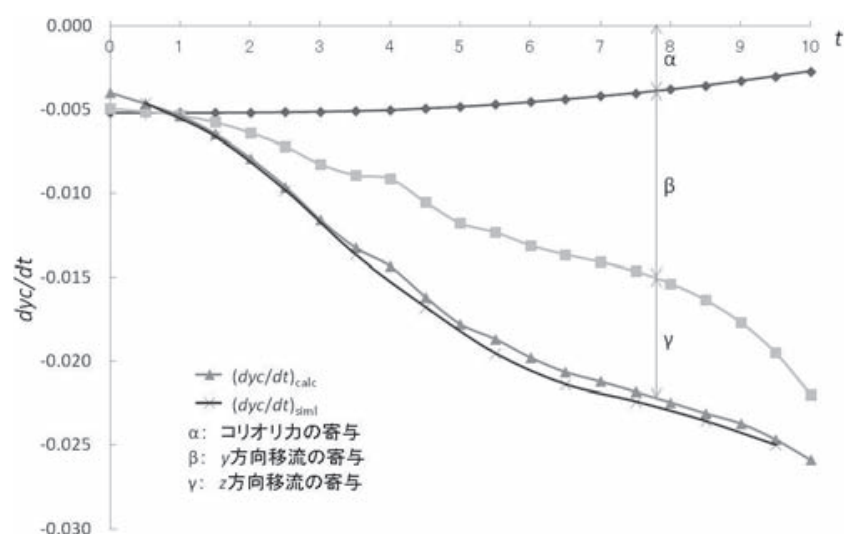

(a) 旋回率 1.0

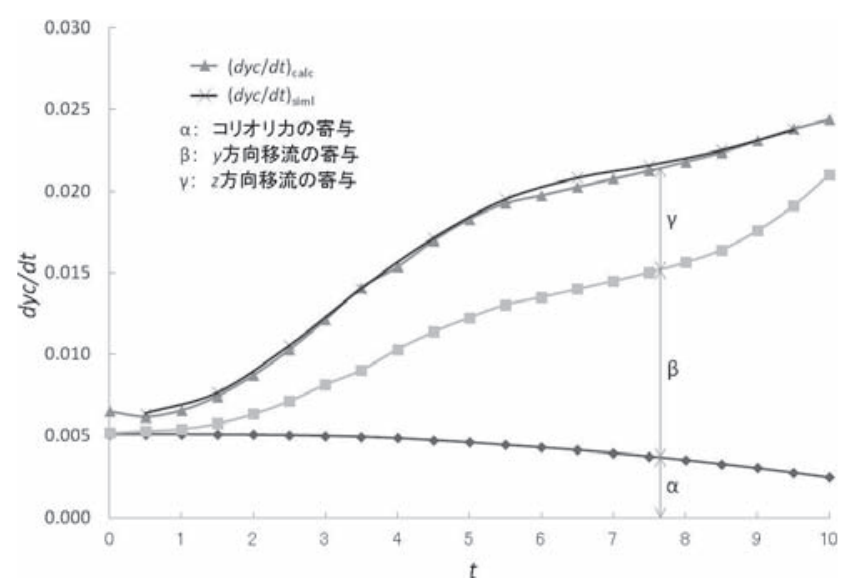

(b) 旋回率 -1.0

第 9 図 噴流中心 $y$ 座標の時間変化率（翼の下を噴流が流れる場合）

らに $\left(\mathrm{d} y_{\mathrm{c}} / \mathrm{d} t\right)_{\text {calc }}$ を構成する各項の值の変化を見ると, 初 期時刻においては第 1 項（コリオリ力の寄与）が主要部分 を占めているが, 時間経過とともに, 第 3 項 $(y$ 方向への 移流の寄与) の絶対值が単調に増加し，第 4 項（ $z$ 方向へ の移流の寄与）の絶対值は一旦増加した後, 減少しはじめ る.この間, 第 1 項の絶対值は徐々に減少していく.これら の傾向は, 旋回率の正負や噴流が翼の上側か下側かによら ず見られるが, 翼の下側を噴流が流れるケースでは, さら に $t=8$ を越えた所で $y$ 方向への移流の寄与が急激に増加 している。このとき，噴流は翼面にほぼ接する位置まで近 づいている（第 6 図 (d) を参照)。なお，スマゴリンスキー モデルを用いて同じ計算を行った場合にも第 8 図 (a), (b), 第 9 図 (a), (b) と定量的にほとんど同じ結果が得られてい て, 例えば時刻 $t=5$ における $\left(\mathrm{d} y_{\mathrm{c}} / \mathrm{d} t\right)_{\operatorname{siml}}$ の值のモデル による差異は, 最も大きい場合で $1.9 \%$, 最も小さい場合で $0.33 \%$ あ゙った. また, 同様の比較において, $\left(\mathrm{d} y_{\mathrm{c}} / \mathrm{d} t\right)_{\text {calc }}$ の值のモデルによる差異は最も大きい場合で $2.6 \%$, 最も小 さい場合で $0.30 \%$ あった.

第 1 項のコリオリ力により噴流中心がスパン方向に移動 するメカニズムは，以下のように説明できる，第 10 図にお いて, 噴流の方向 $(x$ 軸) を紙面に垂直で表面から裏面に 向かう向き, 旋回の向きを時計回りとする。座標系の回転 角速度べクトル $\boldsymbol{\omega}$ は図の左向き, 即ち $y$ 軸と同じ向きと 


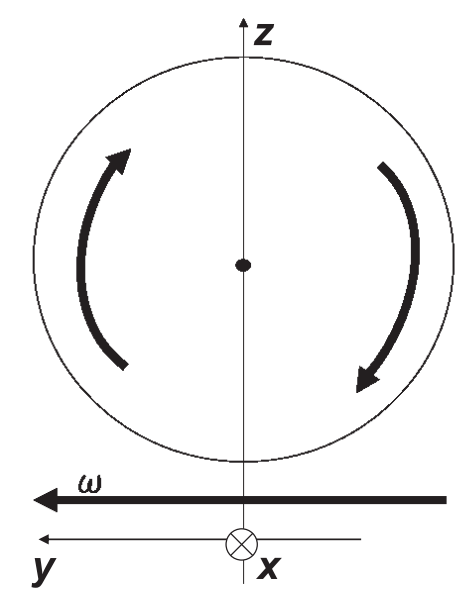

第 10 図噴流と旋回の模式図

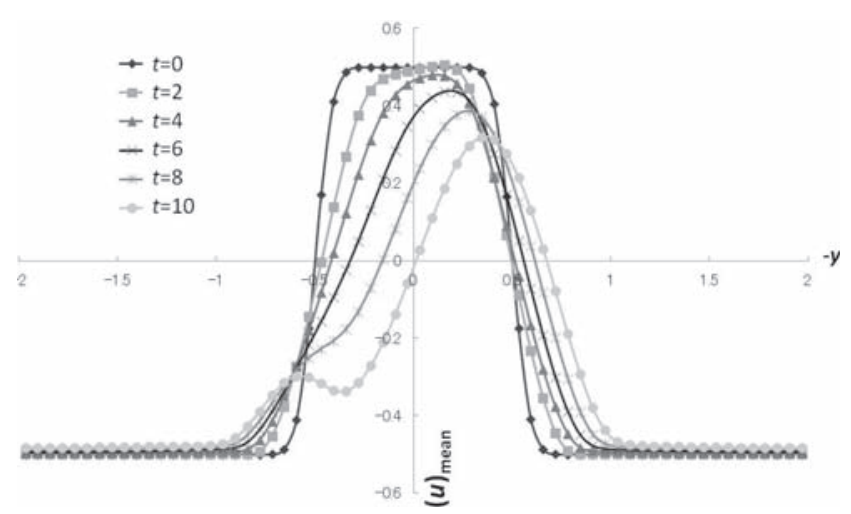

第 11 図 流速の $x$ 成分の $y$ 方向分布（噴流中心を含み $z$ 軸に垂直 な面内）

なる、このとき，旋回運動により生ずるコリオリ力は，図 の左半分では紙面に垂直で表面向き, 即ち噴流を減速させ る方向, 図の右半分では紙面に垂直で裏面向き, 即ち噴流 を加速させる方向に働く，その結果，(7) 式で定義される噴 流中心は右方向に移動する。

初期時刻においては, 平均流速 $\boldsymbol{u}_{\mathrm{m}}$ の分布は噴流中心ま わりに軸対称に設定していて（(2) 式参照), その結果, 乱 れの影響を無視すれば, (10) 式右辺の第 3 項と第 4 項は 0 となることが示せる。 このことは上述のように計算結果に も表れていて, このとき, 噴流中心のスパン方向への移動 は上記のメカニズムによりほぼ説明できる。しかし，時間 経過とともに二次流れが発生し, 噴流内外の速度分布が軸 対称から大きくずれていくことがシミュレーション結果か ら確認されていて, 第 3 項と第 4 項の影響が増加していく ものと考えられる. 具体的にどのような二次流れが発生し ていて，それが噴流中心の移動にどういう形で寄与してい るのかは, 現時点ではまだ詳細が明らかではなく, 今後の 課題として引き続き検討を行っていく，また，ここで解析 を行ったすべてのケースにおいて, ごく初期の時刻を除い て, これら 2 項が常に噴流中心のスパン方向への移動量を 拡大させるように働いていることの原因も不明であり, そ のメカニズムの究明も今後の課題である.
なお，本研究で扱った状況と幾何学的にやや類似した曲 がり管内流れの研究において, 二次流れにより遠心力と逆 向きに流体が移動している領域で管軸方向の流速が極大と なる現象が知られていて, 'Annular phenomenon'と呼ば れている14) が, そのメカニズムが解明されたとの情報は得 られていない，ここで，その現象自体は，本報告の (10) 式 右辺第 1 項の効果についての上記の説明における第 10 図 の右半分での現象と, 少なくとも定性的には一致している ことは注目すべき点と考えられる。第 11 図は，第 8 図 (a) と同じケース（曲率半径 $R=40.0$, 旋回率 $S_{\mathrm{r}}=1.00$, 噴 流内外の流速比 $V_{\mathrm{r}}=2.00$, 翼の上側を噴流が流れるケー ス）のシミュレーションで得られた速度分布から, 各時刻 における噴流中心位置を含み $z$ 軸に垂直な平面近傍での流 速の $x$ 成分 $u$ ( $x$ 方向に平均した值) の $y$ 方向分布を算出 して図示したものである。具体的には，噴流中心を挟む 2 枚の $x y$ 格子面上でそれぞれ算出した值の平均值を表示し た. 図から明らかなように, $t \simeq 6$ 以降において, Annular phenomenon と同様に, 遠心力と逆向きに流体が移動して いる側（図の右側）で流速分布のピークが現れている。な お, 同図においては, 左右の関係を第 10 図と一致させるた め, 横軸を $(-y)$ として表示した.

\section{4. 結論}

湾曲した翼面に沿って流れる噴流の数值解析をラージ . エディ・シミュレーション法を用いて行った。計算におい ては，翼面に沿って噴流と同じ方向に移動する非慣性系を 座標基準系とした。得られた結果は以下の通りである。

1）噴流が旋回していない場合，時間経過とともに噴流に 垂直な断面内で二次流れが発生した。旋回している場合に は，一定時間経過後に渦度の噴流に平行な成分が同断面内 で正の領域と負の領域とに分離し，両領域が旋回と同じ向 きに回転しながら，遠心力の方向にも少しずつ移動した。

2）揚力の大きさの指標となる「翼面に垂直な方向の圧 力勾配」が，噴流のない場合よりも増加した．圧力勾配の 大きさは翼面の曲率半径と噴流内外の流速比により決まり, 噴流の旋回率には関係しない。 また，噴流のない場合に対 する圧力勾配の増加率は, 流速比のみによりほぼ決まるこ とが判明した。

3）噴流中心は, 計算に用いた基準系に対して, 時間経過 とともに遠心力方向とスパン方向に同時に移動する。スパ ン方向への移動は, 旋回の向きによって移動方向も逆転し, 旋回のない場合にはほとんど移動しない.

4）噴流がまわりの流体から受ける圧力の面積分值のスパ ン方向成分はほとんどゼロであり，噴流中心のスパン方向 への移動は外部の流体から受ける圧力によるものではない と推測できる.

5）計算領域内の流体に加わる力としてコリオリ力のみを 考慮した場合における噴流中心のスパン方向への移動量の 理論值は, シミュレーション結果における実際の移動量と ほぼ一致する。

6）平均流速の分布を噴流中心まわりに軸対称に設定した 
初期時刻においては，噴流中心のスパン方向への移動の大 部分は, 旋回によるコリオリ力の分布の不均一により生じ ている．時間経過とともに流速分布の軸対称性が崩れ，噴 流に垂直な断面内での移流の効果による移動量が増加して いく，旋回の向きによらず，移流の効果は噴流中心のスパ ン方向への移動量を拡大させる方向に働く.

\section{参 考 文 献}

1) 保原 充, 桑原宏成, 坪井 淳：2 ジエット式循環制御翼の揚力 特性, 日本航空宇宙学会誌, 31 (1983), pp. 678-684.

2) 佐藤光太郎, 横田和彦：循環制御翼周りの流れに関する研究, 総 合研究所・都市減災研究センター研究報告書, 4.2-2, 2011.

3）高橋 侔, 深沢政広 : 三次元壁面噴流の実験的研究，航空宇宙技 術研究所資料, TM-376, 1978 .

4）飯田誠一, 松田 寿：曲面に沿う円形乱流噴流に関する実験的研 究，日本機械学会論文集 B 編， 54 (1988), pp. 354-360.

5）社河内俊彦，青木利一，上杉正和：三次元円形回壁面噴流に関す る研究，日本機械学会論文集 B 編, 59 (1993), pp. 2157-2164.

6) 檜原秀樹, 須藤浩三：凹面に沿う三次元噴流, 日本機械学会論文 集 B 編, 61 (1995), pp. 2053-2061.
7) 藤澤延行 : 壁面噴流の乱流特性に関する研究, 東北大学博士論文, 1983.

8) Kwak, D., Reynolds, W. C. and Ferziger, J. H.: ThreeDimensional Time Dependent Computation of Turbulent Flow, Rep. TF-5, Mech. Engrg. Dpt. Stanford University, 1975.

9) Maruyama, Y.: Numerical Simulation of Plane Turbulent Shear Layer, Trans. Jpn. Soc. Aeronaut. Space Sci., 31 (1988), pp. 79-93.

10) Mansour, N. N., Ferziger, J. H. and Reynolds, W. C.: Large Eddy Simulation of a Turbulent Mixing Layer, Rep. TF-11, Mech. Engrg. Dpt. Stanford University, 1978.

11）大宮司久明, 三宅 裕, 吉澤 徵: 乱流の数值流体力学一モデル と計算法, 東京大学出版会, 東京, p. 201.

12) Comte-Bellot, G. and Corrsin, S.: Simple Eulerian Time Correlation of Full- and Narrow-Band Velocity Signals in GridGenerated 'Isotropic' Turbulence, J. Fluid Mech., 48 (1971), pp. 273-337.

13）丸山祐一：マグヌス効果の物理的メカニズムについて，日本航空 宇宙学会論文集, 57 (2009), pp. 309-316.

14) Takami, T., Sudou, K. and Sumida, M.: Pulsating Flow in Curved Pipes (1st Report, Numerical and Approximate Analyses), Bull. JSME, 27 (1984), pp. 2706-2713. 